\title{
MUSIC CURRICULUM INTEGRATION PRACTICES - “ACCOUNTABILITY" AS POLICY TRANSLATION IN PROFESSIONAL MUSIC TRAINING: THE CASE OF THE TUT
}

\author{
Hua Hui Tseng \\ Tainan University of Technology (Taiwan)
}

\begin{abstract}
Music curriculum integration in professional music training is a process in which policy and practical issues associated with using student achievement and music teachers' professionalism is considered so that "accountability" may more readily support curriculum integration needs. One of the realities of music education is how government-led implementation of policies influences arts teaching and learning in unintended ways. The purpose of this paper is to use Bate's (2017) three musical experiences of critical social class theory as the enquiry lens. Three contextual variables are highlighted for their impact on teachers and schools: Tolerance, inter-cultural dialogue, and respect for diversity. The focus is music education policy and its aims and strategies that need to be shaped in different ways that are appropriate to the diversity of musical practices and contexts of music education. Insights into the results of policy translation are gained through using the Music Department at the Tainan University of Technology, Taiwan, as an example. The findings demonstrate that music curriculum integration with a function-based approach to accountability helps with successfully implementing policies.
\end{abstract}

Keywords: Curriculum integration, accountability.

\section{Introduction}

Music curriculum integration is performed by people who legislate, create, teach, and learn music and other school subjects. Music curriculum integration, then, is more than just a technical exercise; it is also always social and sociological (Bates, 2016). A growing consensus has evolved that various kinds of arts integration teaching and professional development programs are positively linked to improved student learning (Burnaford, Brown, Doherty, \& McLaughlin, 2007; Catterall, Chapleau, \& Iwanaga, 1999; Catterall \& Waldorf, 1999; Deasy, 2002; Gardiner, 2000). Music curriculum integration in professional music training means the combination of three musical experiences of critical social class theory, namely, tolerance, inter-cultural dialogue, and respect for diversity, within complex learning experiences. Bates (2017) noted that a critical social class theory not only leads to serious acknowledgement, but also looks beyond marginalization. As Perrine (2017) noted, within music education, various themes emerge when discussing music education from a critical perspective: A critique of capitalism as an economic system and its disparate impact on musical opportunities for children; concern regarding neoliberal political policies, which tend to devalue music and the arts as a curricular area; the negative influence on large corporations on mass culture and students' musical horizons; and a concern for minority and disadvantaged students and their musical values. Herbert Marcuse's (1898-1979) discussion and approach to understanding tolerance in 1965 is grounded in the language and ideas of critical theory as a whole. The representation of conservative viewpoints on curriculum theory and philosophical discourse on the role of the large instrumental ensembles in the music curriculum have the capacity to engage all music education practitioners, exciting the imagination and encouraging them to reach the ordinary notion of education (Perrine, 2017). For disadvantaged students, Shared Training Activities for Music Professionals (STAMP) (2018) noted that the Hungarian composer, ethnomusicologist, and teacher Kodály (1882-1967) believed that music should be part and parcel of daily education and accessible to all. The concept of musical youth as intercultural phenomenon celebrates human diversity and social inclusivity. Therefore, in this paper, it is advocated that an intercultural approach must be based on musical meaning theorization and the uses and functions of music and musical identities (participation in the musical experience). Inter-cultural dialogue illustrates the ways that learning in and through trainers/educators' experiences offers the potential and possibility for changing trainers/educators' perceptions of both self and others (Skoutella, 2018). 
Professional music training programs are challenged by major changes in the sociocultural and educational landscape. In response to Taiwan's societal challenges, such as current issues about Music Education Policy, the Ministry of Education, Taiwan, amended the Arts Education Act (AEA) that outlined the curriculum for study in the performing arts in 1997. The AEA of 1997 was related directly to Taiwan's art education reform (Lau \& Li, 2013). This new milestone provided a solid foundation in music education in Taiwan for all students (Ministry of Education, Taiwan, 1997).

Examination of the mismatch is undertaken on three levels. First, on the macro level, Marcuse's philosophy of tolerance that pervades education in Taiwan and other similar Western countries is identified. Second, on the meso level, "accountability" as policy translation is at the center of this paper and therefore, the contextual dimensions (inter-cultural dialogue and respect for diversity) that impact on professional music learning opportunities are identified. Recognizing their contribution to the ecology of higher education will highlight the focus of music curriculum implementation (Mishook \& Kornhaber, 2006). Finally, at the micro level, the intended and unintended results of implementation policy and what this has meant for music education in this scenario is identified.

\section{Background}

\subsection{Music education and practice in the Taiwan's context}

Two main channels of higher education exist in Taiwan: Academic and vocational technology. Tainan, Taiwan, hosts 11 universities: Four are academic, and the remaining seven are vocational technology institutions (Ministry of Education, Taiwan, 2008). Only three of the universities have music departments: Two are academic universities, the National University of Tainan (NUTN) and Tainan National University of the Arts (TNNUA), and one is vocational technology university, namely, Tainan University of Technology (TUT). NUTN, located in the southern metropolitan area of Taiwan, is an historic university with a distinguished academic legacy (National University of Tainan, 2007). TNNUA is the only professional school of the arts located outside of the Taipei metropolitan area. TUT, founded in August 1964, places its emphasis on home economics and arts and is located in Yongkang City, Tainan County's geographic center. There are 30 fulltime faculty in the music department of TUT; 19 faculty are piano majors, which is $63 \%$ of the staff in the music department. In 2020, 9,474 daytime program students were registered in 5 colleges, 6 graduate institutes, 21 departments, and 4 bachelor's degree programs; 497 students are music majors, which is $5.2 \%$. of the students in at the school.

\section{Macro forces: Political engagement by music education practitioners}

As a macro force influencing education across the globe, political engagement by music education practitioners is considerable. The current politicized curriculum in music education has resulted in what Chapmana, Wrighta, and Pascoea (2018) and Chen and Huang (2017) suggested is a rescaling of educational accountability. This rescaling shifts the focus of performance from a predefined false consciousness towards specific political ends, namely, the transformation of capitalist society and the development of "authentic" consciousness (Perrine, 2017) and is being experienced most in Western post-industrialized countries such as the United Kingdom, United States, Canada, Australia, and Taiwan (Chapmana et al., 2018; Chen \& Huang, 2017). Cross-disciplinary work bringing in sources from political science, sociology, law, or economics can help shed light on both alternative and traditional approaches within the discipline of music education (Perrine, 2017). This is important because these political perspectives inform policy and its enactment (Chapmana et al., 2018; Chen \& Huang, 2017).

\section{Meso forces: "Accountability" as policy}

At a meso level, the policy central to this paper is colloquially known as "accountability." In this context, "accountability and performance" recognize policy components to be implemented as published by the Curriculum Mapping, National Taiwan University (NTU), whereas "competition and deregulation" (Chou, 2015) indicates components focused on three values: Spontaneity, interaction, and common good in Taiwan schools (Chen \& Huang, 2017). This policy phrase was introduced by the General Curriculum Guidelines and endorsed by the Ministry of Education, Taiwan, for the purpose of translation from central government to localized responsibility. In this parlance, translation implies taking policy from its written to enacted context. In considering policy as both text and enactment, music education practitioners can better understand the notion of "accountability" as a tool to manage the introduction of a curriculum and discuss why this may or may not produce the intended outcomes for teacher and student engagement with music integration practices in and through the new curriculum. The purpose of the "accountability" policy is to implement the curriculum in such a way as to actually reach students in schools and increase their engagement with a coequal, cognitive style of music curriculum integration. 


\section{Micro forces: Understanding of the "accountability" message}

The "accountability" message has been a powerful tool for higher education institutes (HEIs) in outlining their plans for governance change to increase efficiency in Taiwan's schools. Market-oriented higher education is becoming primarily focused on structures and actions tailored to "competition and deregulation" (Chou, 2015, p.11). Students are expected see connections and walk away with bigger ideas. Policy activities in music education are required to be rooted in a theoretical basis of aims and strategies. Music teachers need to be encouraged to develop their abilities to participate in music education policymaking (Jank, 2009). In addition, Scripp, Ulibarri, and Flax (2013) noted administrators have the power to require accountability measures to show that all of the music programs in their school employ a deep and deliberate practice model for music development. Understanding the "accountability" purpose, to make curriculum more accessible to students, is one component of this paper and highlights the intended outcomes of the "accountability" message.

\section{Conclusion}

Most of the interest groups agree with Hope (2002) that "A policy is a decision about how to proceed, based in part on knowledge or research and in part on values and opinion. Its existence presupposes potential action aligned with the decision reached. Policy is made because of a perceived need to act" (p. 5). However, it is clear that groups of people throughout history and throughout the world have their own associated musics and musicings with music curriculum and its integration with social studies. It is an educator's responsibility to ensure that integration "seeks cost-effective behavior among HEIs, increased efficiency, and eventually better educational quality" (Chou, 2015, p.11) and encourage a more constructivist learning environment when implemented.

\section{References}

Bates, V. C. (2016). Toward a sociology of music curriculum integration. Action, Criticism, and Theory for Music Education 15(3), 8-20.

Bates, V. C. (2017). Critical social class theory for music education. International Journal of Education $\&$ the Arts, 18(7), 1-24.

Burnaford, G., Brown, S., Doherty, J., \& McLaughlin, J. (2007). Arts integration frameworks, research practice. Washington, DC: Arts Education Partnership.

Catterall, J., \& Waldorf, L. (1999). Chicago arts partnerships in education: Summary evaluation. In E. B. Fiske (Ed.), Champions of change: The impact of the arts on learning (pp. 47-62). Washington, DC: The Arts Education Partnership.

Catterall, J., Chapleau, R., \& Iwanaga, J. (1999). Involvement in the arts and human development: General involvement and intensive involvement in music and theater arts. Retrieved from https://pdfs.semanticscholar.org/0b82/1f9743f8e321f283147b5a20ba8dbe0a2f7f.pdf

Chapmana, S., Wrighta, P., \& Pascoea, R. (2018). Arts curriculum implementation: "Adopt and adapt" as policy translation. Arts Education Policy Review, 119(1), 12-24. doi:10.1080/10632913.2016.1201031

Chen, H. L., \& Huang, H.Y. (2017). Advancing 21st century competencies in Taiwan. New York: The Center for Global Education at Asia Society.

Chou, C. P. (2015). Mass higher education development in East Asia. Strategy, quality, and challenges. In C. Shin, J. Postiglione, G. A., Huang, \& X. Futao (Eds.), Chapter 5 Higher Education Development in Taiwan (pp.1-20). Singapore: Springer.

Deasy, R. J. (Ed.). (2002). Critical links: Learning in the arts and student academic and social development. Retrieved from https://www.govinfo.gov/content/pkg/ERIC-ED466413/pdf/ERICED466413.pdf

Gardiner, M. (2000). Music, learning, and behavior: A case for mental stretching. Journal for Learning Through Music, 1, 72-93.

Hope, S. (2002). Policy frameworks, research, and K-12 schooling. In R. Colwell \& C. Richardson (Eds.), The new handbook of research on music teaching and learning: A project of the music educators national conference (pp. 5-16). New York: Oxford University Press.

Jank, W. (2009). Moving in a field of conflicting forces: Problems of music education policy in Germany. Arts Education Policy Review, 110(4), 14-21. doi:10.3200/AEPR.110.4.14-21 
Lau, H. F., \& Li, C. (2013) (Eds.). Curriculum innovations in changing societies: Chinese perspectives from Hong Kong, Taiwan and Mainland China. Retrieved from https://www.sensepublishers.com/media/1767-curriculum-innovations-in-changing-societies.pdf

Marcuse, H. (1965). Repressive tolerance. Boston, MA: Beacon Press.

Ministry of Education, Taiwan (1997). Retrieved from https://law.moj.gov.tw/ENG/LawClass/LawHistory.aspx?pcode=H0170037

Ministry of Education, Taiwan. (2008). Study in Taiwan. Retrieved from http://english.moe.gov.tw/content.asp?CuItem $=678$

Mishook, J. J., \& Kornhaber, M. L. (2006). Arts integration in an era of accountability. Heldref Publications, 107(4), 3-11. doi:10.3200/AEPR.107.4.3-11

National University of Tainan. (2007). Brief history. Retrieved from http://web. nutn.edu.tw/english/brief_history.htm

Perrine, W. M. (2017). The perils of repressive tolerance in music education curriculum. Action, Criticism, and Theory for Music Education, 16(2), 6-38. doi:10.22176/act16.2.6

Scripp, L., Ulibarri, D., \& Flax, R. (2013). Thinking beyond the myths and misconceptions of talent: Creating music education policy that advances music's essential contribution to twenty-firstcentury teaching and learning. Arts Education Policy Review, 114, 54-102. doi:10.1080/10632913.2013.769825

Shared Training Activities for Music Professionals. (2018). Training and lifelong learning for music professionamp-music.org/

Skoutella, A. P. (2018). A multicultural/intercultural conceptual framework for training music professionals for disadvantage youth, social inclusion and music-Suggested activities and model of implementation. Erasmus+ KA2 STAMP Project-Social Inclusion in Music. 